\title{
A haemagglutinating adhesin of group B streptococci isolated from cases of bovine mastitis mediates adherence to HeLa cells
}

\author{
I Wayan Teguh Wibawan, ${ }^{1}$ Christoph Lämmler, ${ }^{1 *}$ Ragy S. Seleim ${ }^{1}$ \\ and FACHRIYAN H. PASARIBU ${ }^{2}$ \\ ${ }_{1}^{1}$ Institut für Bakteriologie und Immunologie, Justus-Liebig-Universität, Frankfurter Straße 107, 6300 Gießen, \\ Germany \\ ${ }^{2}$ Department of Infectious Diseases and Veterinary Public Health, Faculty of Veterinary Medicine, IPB, \\ Jl. Taman Kencana 3, Bogor, Indonesia
}

(Received 12 November 1992; revised 20 April 1993; accepted 7 May 1993)

\begin{abstract}
Rabbit erythrocytes were agglutinated by $43.4 \%$ of group B streptococci isolated from bovines but by none isolated from humans. Haemagglutination was enhanced by cultivation of the bacteria under microaerophilic conditions. Most of the haemagglutinating strains had protein type antigen $X$, either alone, or in combination with polysaccharide antigens. Heat and proteolytic treatment of the bacteria destroyed the haemagglutination activity. The haemagglutinin could be solubilized from the bacterial surface by mutanolysin treatment and isolated from culture supernatant fluid by ammonium sulphate precipitation. The isolated haemagglutinin did not cause direct agglutination of erythrocytes. However, binding of the haemagglutinin to rabbit erythrocytes could be visualized by agglutination of haemagglutinin-treated erythrocytes by specific antiserum obtained by absorption. Western blotting showed that the haemagglutinin obtained from erythrocyte lysates contained an antibody-reactive band with a molecular mass of $43 \mathrm{kDa}$. Haemagglutination-positive strains adhered to HeLa cells in higher numbers than did haemagglutination-negative strains. The HeLa cell adherence of Group B streptococci was inhibited in the presence of isolated haemagglutinin or of specific antiserum against the haemagglutinin. These observations suggest that the haemagglutinating adhesins of bovine group B streptococcal isolates are directly involved in the adherence mechanisms of these organisms.
\end{abstract}

\section{Introduction}

Bacterial infections are generally initiated by the adherence of pathogenic bacteria to epithelial cells of the host organism. Adherence to host cells appears to be a multifactorial phenomenon involving specific as well as nonspecific, physicochemical interactions. Structures that are probably responsible for bacterial adhesion include fimbriae and non-fimbrial adhesins, such as lipoteichoic acid or adhesins of protein nature. Some mechanisms for adhesion and bacterial colonization of mucosal surfaces were summarized by Arp (1988). The physicochemical interactions involved in adhesion are mainly contributed by hydrophobic surface structures (Doyle \& Rosenberg, 1990).

The ability of bacteria to attach to and agglutinate erythrocytes has been used in vitro as a model for studying interactions between bacteria and their hosts. A relation between haemagglutinating properties and the

*Author for correspondence. Tel. 0641702 4835; fax 06417027390. ability of the bacteria to adhere to host cells has been observed for various bacterial species (Deslauriers \& Mouton, 1992; Hoschützky et al., 1989; Kanoe et al., 1992; Kurl et al., 1989). The present study was designed to study haemagglutinating properties of bovine isolates of group B streptococci and the possible role the haemagglutinin might play in mediating adherence of the bacteria to host cells.

\section{Methods}

Bacteria. A total of 150 streptococcal isolates of serological group B were used in this study. The cultures included the type reference strains 090 (serotype Ia), H36B (Ib), 18 RS 2 I (II), 6313 (III), 3139 (IV), SS 1169 (V), A909 (Ic), 24/60 (NT/X) and 25/60 (NT/R), 83 group B streptococcal isolates from cases of bovine mastitis, and 58 group $B$ streptococcal isolates from humans. The cultures were serotyped and further characterized as described previously (Wibawan \& Lämmler, 1990, 1992). The bacteria were grown in Todd-Hewitt broth (THB, Gibco) for $18 \mathrm{~h}$ at $37^{\circ} \mathrm{C}$ either under microaerophilic conditions in a candle jar or under aerobic conditions on a rotary shaker (60 r.p.m.)

In parallel experiments the haemagglutinating strain Actinomyces naeslundii 52 was used (Lämmler et al., 1987). 
Erythrocytes. Blood was collected from healthy rabbits, with $0.2 \mathrm{M}-$ sodium citrate, $\mathrm{pH} 5 \cdot 2$, used as an anticoagulant. The erythrocytes were sedimented by centrifugation $(2500 \mathrm{~g}, 10 \mathrm{~min})$, washed twice with $0.15 \mathrm{M}-\mathrm{NaCl}$ and diluted in isotonic $\mathrm{NaCl}$ to a $2 \%(\mathrm{v} / \mathrm{v})$ working suspension. In parallel experiments the erythrocytes were washed with $0.2 \mathrm{M}$-sodium acetate buffer $(\mathrm{pH} 5 \cdot 2)$ treated with neuraminidase $[100 \mu 1$ erythrocyte suspension and $100 \mu$ distilled water containing $0 \cdot 1 \mathrm{U}$ neuraminidase (type $\mathrm{V}$ neuraminidase from Clostridium perfringens, Sigma)] (Lämmler et al., 1987), washed in $0.15 \mathrm{M}-\mathrm{NaCl}$ and diluted to the original working suspension.

Haemagglutination assay. Haemagglutination tests were carried out with $20 \mu \mathrm{l}$ of the respective culture, adjusted photometrically (Bausch and Lomb) to $10 \%$ transmission at $620 \mathrm{~nm}\left(10^{9}\right.$ bacteria $\mathrm{ml}^{-1}$ in $0.15 \mathrm{M}-\mathrm{NaCl}$ ) and $20 \mu \mathrm{l}$ of rabbit erythrocytes on microscope slides. The slides were rotated gently and within $30 \mathrm{~s}$ the haemagglutination was recorded as strong agglutination $(++)$, agglutination $(+)$ or no agglutination (-).

In inhibition experiments $20 \mu \mathrm{l}$ of each bacterial suspension $\left(10^{9}\right.$ bacteria $\mathrm{ml}^{-1}$ ) was preincubated for $1 \mathrm{~min}$ with $20 \mu \mathrm{l}$ of $50 \mathrm{~mm}$ solutions of the sugars $\mathrm{L}(+)$ rhamnose, $\mathrm{D}(+)$ galactose, $\mathrm{D}(+)$ lactose, $\mathrm{D}(+)$ glucosamine, $N$-acetyl-D-glucosamine or $\mathrm{D}(+)$ mannose (Sigma), or with $20 \mu \mathrm{l} 0.2 \mathrm{M}$-EDTA, and subsequently used in the haemagglutination assay. In parallel experiments the haemagglutination assay was performed in the presence of $20 \mu \mathrm{l} 0.2 \mathrm{M}$-EDTA and $20 \mu \mathrm{l} 3 \mathrm{mM}-$ $\mathrm{CaCl}_{2}$.

Treatment of bacterial cells. To study the effect of various treatments of the bacteria on haemagglutinating activities, selected isolates were heated at $50^{\circ} \mathrm{C}$ for 10,30 or $60 \mathrm{~min}$, or incubated with proteolytic enzymes. The latter treatment was performed with $50 \mu \mathrm{g}$ trypsin or pronase $\mathrm{E}$ (Merck) per ml of spectrophotometrically adjusted bacterial suspension $\left[10^{9}\right.$ bacteria $\mathrm{ml}^{-1}$ in phosphate-buffered saline (PBS, $\mathrm{g}^{-1}$ : $\left.\left.\mathrm{Na}_{2} \mathrm{HPO}_{4}, 12 \cdot 14 ; \mathrm{NaCl}, 4.35 ; \mathrm{pH} 7.5\right)\right]$ for $1 \mathrm{~h}$ at $37^{\circ} \mathrm{C}$. The bacteria were subsequently washed in $0.15 \mathrm{M}-\mathrm{NaCl}$ and used in the haemagglutination assay. In parallel experiments the bacteria $\left(10^{9}\right.$ bacteria $\mathrm{ml}^{-1}$ in sodium acetate buffer, $\mathrm{pH} 5.2$ ) were treated with $0.1 \mathrm{U}$ neuraminidase $\mathrm{ml}^{-1}$ (type $\mathrm{V}$ neuraminidase from Clostridium perfringens in distilled water) washed in $0.15 \mathrm{M}-\mathrm{NaCl}$ and used in the haemagglutination assay.

Preparation of specific antiserum against the group B streptococcal haemagglutinin. The type-specific antiserum against haemagglutinationpositive group B streptococcal reference strain 24/60, with type antigen pattern NT/X, was absorbed with haemagglutination-negative group B streptococcal strain 781, also exhibiting type antigen pattern NT/X. The specificity of the absorbed antiserum was tested in immunodiffusion reactions: it did not react with group B streptococcal group or type antigen preparations. For haemagglutination inhibition tests, $20 \mu \mathrm{l}$ of bacterial suspensions $\left(10^{y}\right.$ bacteria $\left.\mathrm{ml}^{-1}\right)$ of a haemagglutination-positive group B streptococcal culture was preincubated with $20 \mu \mathrm{l}$ of absorbed antiserum for $5 \mathrm{~min}$ and subsequently used in the haemagglutination assay. For control purposes the bacteria were preincubated with monospecific antisera against haemagglutinationnegative reference strains 18 RS 21 (II) and 3139 (IV), and with serum of a nonimmunized rabbit.

Isolation of haemagglutinin. Haemagglutination-positive and -negative group B streptococcal cultures were cultivated in 1 litre of THB for $18 \mathrm{~h}$ at $37^{\circ} \mathrm{C}$ under microaerophilic conditions in a candle jar, centrifuged, washed with PBS and resuspended in $5 \mathrm{ml}$ PBS containing $100 \mathrm{U}$ mutanolysin (Sigma). The suspension was incubated for $1 \mathrm{~h}$ at $37^{\circ} \mathrm{C}$. Solubilized material was separated from cell debris by centrifugation $\left(10000 \mathrm{~g}, 10 \mathrm{~min}, 4^{\circ} \mathrm{C}\right)$ and the supernatant was dialysed against distilled water for $48 \mathrm{~h}$ at $4^{\circ} \mathrm{C}$. In parallel experiments the culture supernatant fluid of the group B streptococci was precipitated with $70 \%$ saturated ammonium sulphate $\left(472 \mathrm{~g} \mathrm{l}^{-1}\right)$ for $24 \mathrm{~h}$ at $4{ }^{\circ} \mathrm{C}$.
The precipitate was harvested by centrifugation, resuspended in $5 \mathrm{ml}$ PBS and dialysed against distilled water for $48 \mathrm{~h}$ at $4{ }^{\circ} \mathrm{C}$.

Binding of solubilized and precipitated haemagglutinin to rabbit erythrocytes. This experiment was performed as described by Lindahl et al. (1990). Dialysed mutanolysin extract $(2 \mathrm{ml})$ or ammonium sulphate precipitate $(2 \mathrm{ml})$ was incubated with $1 \mathrm{ml}$ of $2 \%(\mathrm{v} / \mathrm{v})$ rabbit erythrocyte suspension for $\mathrm{l} h$ at room temperature. After centrifugation $(1500 \mathrm{~g}, 10 \mathrm{~min})$ the erythrocytes were lysed with $300 \mu \mathrm{l} 2 \%$ (w/v) SDS and dialysed against distilled water for $48 \mathrm{~h}$ at $4{ }^{\circ} \mathrm{C}$. The molecular mass of the haemagglutinin was estimated using an $11 \%$ SDS-polyacrylamide separating gel (Weber \& Osborn, 1969) and Western blotting (Towbin et al,, 1979), for which the nitrocellulose membranes were developed with haemagglutinin-specific antibodies (diluted $1: 25)$, skimmed milk $[10 \%$ in $0.05 \mathrm{~mm}$-Tris-buffered saline $(0.14 \mathrm{~mm}-\mathrm{NaCl}), \mathrm{pH} 7.4]$ as blocking solution and peroxidaseconjugated anti-rabbit immunoglobulins from pigs ( $1: 250$, Dakopatts). For control purposes lysates obtained from rabbit erythrocytes which had been incubated with mutanolysin extracts of a haemagglutinationnegative group B streptococcal culture and serum from a nonimmunized rabbit were used.

Adherence to HeLa cells. HeLa S3 cells were grown for $24 \mathrm{~h}$ at $37^{\circ} \mathrm{C}$ in minimum essential medium (MEM, Sigma) containing $10 \%(\mathrm{v} / \mathrm{v})$ foetal calf serum (Gibco), in cell culture dishes containing glass slides $(10 \mathrm{~mm} \times 20 \mathrm{~mm})$ to form a nonconfluent monolayer. The glass slides were then submerged in Petri dishes containing $4 \mathrm{ml}$ Hanks' balanced salt solution (HBSS, Sigma) and subjected to the adherence assay. For this assay the bacteria were grown for $18 \mathrm{~h}$ at $37^{\circ} \mathrm{C}$ in THB under microaerophilic conditions in a candle jar, centrifuged, washed with HBSS, adjusted spectrophotometrically to $10^{9}$ bacteria $\mathrm{ml}^{-1}$ and stained with fluorescein isothiocyanate (FITC, $1 \mathrm{mg} \mathrm{ml}^{-1}$ in HBSS) for $\mathrm{l} \mathrm{h}$ at room temperature at a final concentration of $0.25 \mathrm{mg}$ FITC per $\mathrm{ml}$ of bacterial suspension. The bacteria were washed twice with HBSS and stored at $4{ }^{\circ} \mathrm{C}$ until use. To study the adherence properties of the bacteria, $100 \mu \mathrm{l}$ of the bacterial suspension was added to the HeLa-cellcoated slides in $2 \mathrm{ml}$ HBSS and incubated for $1 \mathrm{~h}$ at $37^{\circ} \mathrm{C}$. The slides were then gently washed with HBSS containing $0.05 \%$ Tween 20 . The number of adhering bacteria was counted with a fluorescence microscope.

In parallel experiments the adherence tests were performed with bacteria pretreated with specific antiserum against haemagglutinin or serum of a nonimmunized rabbit $\left(10^{9}\right.$ bacteria $\mathrm{ml}^{-1}, 50 \mu \mathrm{l}$ serum, $1 \mathrm{~h}$, $37^{\circ} \mathrm{C}$ ). In addition, the HeLa cells were used after pretreatment with $50 \mu$ isolated haemagglutinin. The haemagglutinin was recovered from SDS lysates of rabbit erythrocytes pretreated with mutanolysin extracts or ammonium sulphate precipitate from culture supernatant fluid of a haemagglutination-positive group B streptococcal cultures as described. Lysates from rabbit erythrocytes were used as control.

\section{Results}

\section{Haemagglutination}

Of the 83 group B streptococcal strains of bovine origin used in this study, $36(43.4 \%)$ agglutinated rabbit erythrocytes. The reference strain $24 / 60$ with type antigen pattern NT/X also agglutinated rabbit erythrocytes. All other reference strains and all strains isolated from humans were non-haemagglutinating. Of the 36 haemagglutination-positive strains, 30 had type antigen $\mathrm{X}$, either alone or in combination with type antigen II or IV, one had the type antigen pattern II $/ \mathrm{c}$ and five were non-typable. Twice as many bovine isolates 
Table 1. Distribution of haemagglutination reactions with rabbit erythrocytes among group B streptococcal isolates of various serotypes grown under microaerophilic and aerobic conditions

\begin{tabular}{|c|c|c|c|c|c|c|c|}
\hline \multirow{3}{*}{$\begin{array}{l}\text { B streptococcal } \\
\text { strains }\end{array}$} & \multirow{3}{*}{$\begin{array}{l}\text { No. of } \\
\text { strains }\end{array}$} & \multicolumn{6}{|c|}{ No. showing haemagglutination* } \\
\hline & & \multicolumn{3}{|c|}{ Microaerophilic } & \multicolumn{3}{|c|}{ Aerobic } \\
\hline & & ++ & + & - & ++ & + & - \\
\hline \multicolumn{8}{|l|}{ Bovine serotypes } \\
\hline II & 8 & 0 & 0 & 8 & 0 & 0 & 8 \\
\hline $\mathrm{Il} / \mathrm{c}$ & 8 & 0 & 1 & 7 & 0 & 1 & 7 \\
\hline $\mathrm{II} / \mathrm{X}$ & 4 & 3 & 1 & 0 & 0 & 0 & 4 \\
\hline IV & 14 & 0 & 0 & 14 & 0 & 0 & 14 \\
\hline IV $/ \mathrm{c}$ & 9 & 0 & 0 & 9 & 0 & 0 & 9 \\
\hline IV $/ X$ & 18 & 18 & 0 & 0 & 1 & 11 & 6 \\
\hline $\mathrm{NT} / \mathrm{X}$ & 10 & 5 & 3 & 2 & 0 & 4 & 6 \\
\hline $\mathrm{NT}$ & 12 & I & 4 & 7 & 0 & 0 & 12 \\
\hline \multicolumn{8}{|l|}{ Human isolates } \\
\hline Various serotypes & 58 & 0 & 0 & 58 & 0 & 0 & 58 \\
\hline
\end{tabular}

*Haemagglutination activity after growth under the conditions shown: ++ , strong haemagglutination; + , haemagglutination; - , no haemagglutination.

were haemagglutinating after growth under microaerophilic conditions as under aerobic conditions (Table 1).

Heat treatment of the bacteria for $30 \mathrm{~min}$ at $50^{\circ} \mathrm{C}$ abolished the haemagglutination activities, as did trypsin and pronase treatment, indicating that the haemagglutinin was proteinaceous. Treatment of the rabbit erythrocytes or the haemagglutinating bacteria with neuraminidase had no effect on haemagglutination. Selected haemagglutination-negative group B streptococci from bovines and humans were still negative after neuraminidase treatment. In contrast, the haemagglutination reaction of Actinomyces naeslundii was enhanced after neuraminidase treatment of the rabbit erythrocytes.

The haemagglutination reactions of the group B streptococci and of $A$. naeslundii were abolished by the addition of EDTA. The addition of $\mathrm{CaCl}_{2}$ to EDTApretreated bacteria restored the haemagglutination reactions. The presence of $\mathbf{L}(+)$ rhamnose, $\mathrm{D}(+)$ galactose, $\mathrm{D}(+)$ lactose, $\mathrm{D}(+)$ glucosamine, $N$-acetyl-D-glucosamine and $\mathrm{D}(+)$ mannose had no effect on the haemagglutination reactions of the group B streptococci. The haemagglutination of $A$. naeslundii was inhibited in the presence of $\mathrm{D}(+)$ lactose and $\mathrm{D}(+)$ galactose.

The surface proteins responsible for the haemagglutination reactions could be solubilized by mutanolysin treatment of the bacteria or be precipitated from culture supernatant by ammonium sulphate. Rabbit erythrocytes were incubated with both haemagglutinin preparations and subsequently lysed by the addition of SDS.

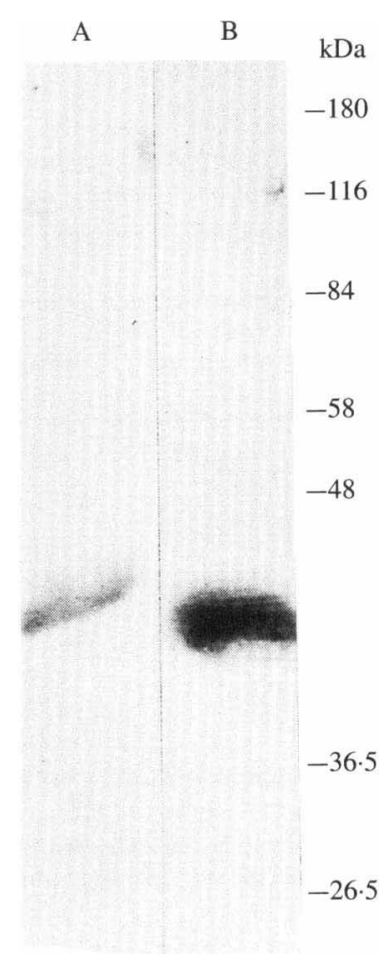

Fig. 1. Western blot analysis of haemagglutinin preparations from mutanolysin extract (A) and ammonium sulphate precipitate of culture supernatant fluid (B) from group B streptococcal strain 395/2. The nitrocellulose membranes were developed with haemagglutinin-specific antiserum.

Both the mutanolysin-released and the ammoniumsulphate-precipitated lysates reacted specifically with the haemagglutinin-specific antiserum in immunodiffusion reactions. No precipitation reaction was observed with serum of a nonimmunized rabbit or with antisera against non-haemagglutinating strains. Incubation of rabbit erythrocytes with crude haemagglutinin preparations or with both lysates did not cause direct haemagglutination. Haemagglutination was observed after the addition to haemagglutinin-treated rabbit erythrocytes of specific antiserum prepared against the haemagglutinin (see Methods), thereby demonstrating binding to the erythrocytes. Control serum of a non-immunized rabbit or monospecific antisera against haemagglutination-negative group B streptococci had no effect. Preparations obtained from a haemagglutination-negative group B streptococcal culture were negative in all these tests.

SDS-PAGE and Western blot analysis of the lysates revealed a reactive band with a molecular mass of $43 \mathrm{kDa}$. The Western blot was developed with haemagglutinin-specific antiserum. Controls with serum of a non-immunized rabbit or lysates from erythrocytes obtained after incubation of the erythrocytes with mutanolysin extracts of a haemagglutination-negative group B streptococcus showed no comparable reaction (Fig. 1). 
Table 2. Adherence of selected haemagglutination-positive group $B$ streptococcal isolates of bovine origin to HeLa cells before and after various treatments

\begin{tabular}{|c|c|c|c|c|}
\hline \multirow{3}{*}{$\begin{array}{l}\text { Potential } \\
\text { inhibitor in } \\
\text { adherence } \\
\text { assay* }\end{array}$} & \multicolumn{4}{|c|}{ No. of adherent bacteria per HeLa cell } \\
\hline & \multicolumn{2}{|c|}{ Haemagglutinating } & \multicolumn{2}{|c|}{ Non-haemagglutinating } \\
\hline & $395 / 2$ & 747 & 781 & G28 \\
\hline Control & $\begin{array}{c}115 \cdot 90 \pm 2 \cdot 65 \\
(112 \cdot 10-118 \cdot 25)\end{array}$ & $\begin{array}{l}108 \cdot 78 \pm 6 \cdot 31 \\
(99 \cdot 35-112 \cdot 85)\end{array}$ & $\begin{array}{c}6 \cdot 45 \pm 1 \cdot 05 \\
(5 \cdot 10-7.35)\end{array}$ & $\begin{array}{r}4.89 \pm 0.63 \\
(4.05-5.40)\end{array}$ \\
\hline Haem-M & $\begin{array}{c}8.53 \pm 2-06 \\
(6.55-10.95)\end{array}$ & $\begin{array}{c}8.35 \pm 3.25 \\
(5 \cdot 10-12.60)\end{array}$ & $\begin{array}{l}\text { ND } \\
\text { ND }\end{array}$ & $\begin{array}{l}\text { ND } \\
\text { ND }\end{array}$ \\
\hline Haem-S & $\begin{array}{l}13 \cdot 33 \pm 5.97 \\
(6 \cdot 10-16.95)\end{array}$ & $\begin{array}{c}7 \cdot 50 \pm 2 \cdot 40 \\
(3 \cdot 95-9 \cdot 15)\end{array}$ & $\begin{array}{l}\text { ND } \\
\text { ND }\end{array}$ & ND \\
\hline Haem-As & $\begin{array}{c}7 \cdot 83 \pm 3 \cdot 35 \\
(4 \cdot 15-11 \cdot 40)\end{array}$ & $\begin{array}{c}9 \cdot 08 \pm 3 \cdot 42 \\
(5 \cdot 70-13 \cdot 35)\end{array}$ & $\begin{array}{l}\text { ND } \\
\text { ND }\end{array}$ & $\begin{array}{l}\text { ND } \\
\text { ND }\end{array}$ \\
\hline NS & $\begin{array}{c}111 \cdot 03 \pm 3 \cdot 11 \\
(108 \cdot 45-109 \cdot 55)\end{array}$ & $\begin{array}{l}112 \cdot 20 \pm 16 \cdot 11 \\
(89 \cdot 60-126 \cdot 70)\end{array}$ & $\begin{array}{l}\text { ND } \\
\text { ND }\end{array}$ & $\begin{array}{l}\text { ND } \\
\text { ND }\end{array}$ \\
\hline
\end{tabular}

${ }^{*}$ Haem-M, $50 \mu \mathrm{l}$ haemagglutinin preparation from mutanolysin extracts; Haem-S, $50 \mu \mathrm{l}$ haemagglutinin from ammonium sulphate precipitate of culture supernatant fluid; Haem-As, $100 \mu \mathrm{l}$ specific antiserum against haemagglutinin; NS, $100 \mu \mathrm{l}$ serum of a non-immunized rabbit.

\section{Adherence to HeLa cells}

Selected representative haemagglutination-positive and haemagglutination-negative group B streptococcal strains $(395 / 2,747$ and $781, \mathrm{G} 28$, respectively) were used in HeLa cell adherence tests. The haemagglutinationpositive group B streptococci adhered to $\mathrm{HeLa}$ cells with more than 100 bacteria per HeLa cell, but fewer than 10 bacteria adhered per HeLa cell for the haemagglutination-negative strains (Table 2).

The adherence of haemagglutination-positive group B streptococci to HeLa cells was greatly reduced in the presence of haemagglutinin preparations obtained from lysates of erythrocytes incubated with mutanolysin extracts or from lysates of erythrocytes incubated with ammonium sulphate precipitates of culture supernatant fluid. No inhibition of adherence was observed with lysates from control erythrocytes. A comparable inhibition of HeLa cell adherence was observed in the presence of specific antiserum against haemagglutinin. Serum of a non-immunized rabbit had no effect (Table 2).

\section{Discussion}

The attachment of bacteria to erythrocytes, leading to haemagglutination, has been described as a common property of streptococci of serological group $\mathrm{G}$, but less pronounced among those of serological groups $\mathrm{C}$ and $\mathrm{D}$. Among 130 group B streptococci examined by Kurl et al.
(1989), only one culture displayed haemagglutinating activities. The low number of haemagglutination-positive cultures observed might have been related to the origin of the group B streptococci. In the present study 36 of 83 bovine group $B$ streptococci isolates agglutinated rabbit erythrocytes. In contrast, none of the group B streptococcal isolates from humans did so.

Most of the haemagglutination-positive group B streptococci, including type reference strain $24 / 60$, had type antigen $\mathrm{X}$, either alone, or in combination with polysaccharide antigens. However, the haemagglutinating properties seemed not to be directly related to the occurrence of type antigen $X$, because haemagglutinating activities were also observed among non-typable strains and with a group B streptococcal strain with type antigen pattern $\mathrm{II} / \mathrm{c}$. Compared to the results of previous studies (Wibawan \& Lämmler, 1992; Wibawan et al., 1992) it was of interest that all the haemagglutinationpositive group B streptococci displayed hydrophobic surface properties. However, not all strains with hydrophobic surface structures were haemagglutinationpositive. In addition the haemagglutinating activities were markedly influenced by the cultivation conditions. Under microaerophilic conditions the number of haemagglutination-positive bacteria increased. Cultivation under microaerophilic conditions has also been shown to enhance the microcapsule production of group B streptococci (Wibawan \& Lämmler, 1992). However, the haemagglutinating activities seemed not to be influenced by the neuraminic acid part of the group B streptococcal microcapsule: the removal of neuraminic 
acid by neuraminidase treatment did not alter the haemagglutination reactions and did not yield a positive haemagglutination reaction with haemagglutinationnegative strains. In contrast, a masking effect of neuraminic acid has been observed for hydrophobic surface proteins and fibrinogen-binding structures (Chhatwal et al., 1984; Wibawan \& Lämmler, 1991, 1992).

In addition, treatment of the rabbit erythrocytes with neuraminidase did not change the haemagglutination activities. This corresponded to the findings of Kurl et al. (1989). The haemagglutinin of the group B streptococci was susceptible to heat and proteolytic treatment of the bacteria, indicating its protein nature. As already described for $A$. naeslundii (Lämmler et al., 1987) the haemagglutination of group B streptococci could be inhibited by EDTA, showing the $\mathrm{Ca}^{2+}$-dependency of the reaction. Comparable to the findings of Kurl et al. (1989), none of the sugars used in this study inhibited group B streptococcal haemagglutination reactions.

The haemagglutinin of group B streptococci could be solubilized from the bacterial surface by mutanolysin treatment or isolated from culture supernatant fluid by ammonium sulphate precipitation. This indicates that the haemagglutinin is not only cell bound but also released into the culture medium. Neither haemagglutinin preparation caused a direct agglutination of the rabbit erythrocytes. However, binding of both agglutinins to the erythrocytes could be visualized by an agglutination reaction with a haemagglutinin-specific antiserum. Both types of haemagglutinin preparations could be released from the erythrocyte surface by SDS treatment of the erythrocytes. After SDS-PAGE and Western blotting a single band with a molecular mass of $43 \mathrm{kDa}$ was identified by using absorbed antiserum.

Both haemagglutinin preparations seemed to mediate the adherence of the bacteria to HeLa cells. Haemagglutination-positive group B streptococci adhered in higher numbers to HeLa cells than did haemagglutination-negative strains. In addition, haemagglutinin preparations and specific antiserum against haemagglutinins almost completely inhibited the interaction between the bacteria and the HeLa cells.

The initial step in bacterial infection involves the contact of the bacterial surface with host cells. For group B streptococci, lipoteichoic-acid-mediated adherence and adherence without lipoteichoic acid involvement has been reported (Miyazaki et al., 1988; Nealon \& Mattingly, 1984; Wibawan et al., 1992). The latter included hydrophobic interactions. According to Nealon \& Mattingly (1984) hydrophobic interactions are the first step in binding to embryonic and foetal cells, followed by a secondary attachment involving lipoteichoic acid. The adherence to epithelial cells may involve only one process, that is hydrophobic interaction. Bramley \& Hogben (1982) reported a protein-mediated adherence of group B streptococci.

The results of the present study show that at least for bovine group B streptococcal isolates a haemagglutinating adhesin seems to be involved in adherence. This haemagglutinin might be one part of multiple group B streptococcal adhesins and contribute to the ability of these organisms to adhere to mucosal surfaces. The occurrence of multiple adhesins in streptococcal species has been reviewed by Hasty et al. (1992). In addition, the present results contribute to previous findings that group B streptococci could be divided into hydrophobic, haemagglutinating, cell-adherent strains and hydrophilic, non-haemagglutinating, encapsulated strains. The latter are less readily phagocytosed by polymorphonuclear leucocytes (Wibawan et al., 1992). As described by Sellin et al. (1992) both properties might occur in phase variants of individual group B streptococcal strains.

\section{References}

ArP, L. H. (1988). Bacterial infection of mucosal surface: an overview of cellular and molecular mechanisms. In Virulence Mechanisms of Bacterial Pathogens, pp. 3-27. Washington, DC: American Society for Microbiology.

Bramley, A. J. \& Hogben, E. M. (1982). The adhesion of human and bovine isolates of Streptococcus agalactiae (group B) to bovine mammary gland epithelial cells. Journal of Comparative Pathology 92. 131-137.

Chhatwal, G. S., Lämmler, C. \& Blobel, H. (1984). Guanidine extraction enhances the binding of human fibrinogen to group $B$ streptococci. Medical Microbiology and Immunology 173, 18-27.

Deslauriers, M. \& Mouton, C. (1992). Epitope mapping of hemagglutinating adhesin HA-Ag2 of Bacteroides (Porphyromonas) gingivalis. Infection and Immunity 60, 2791-2799.

Doyle, R. J. \& Rosenberg, M. (1990). Microbial Cell Surface Hydrophobicity, pp. 1-37. Washington, DC: American Society for Microbiology.

Hasty, D. L., Ofek, I., Courtney, H. S. \& Doyle, R. J. (1992). Multiple adhesins of streptococci. Infection and Immunity 60, 2147-2152.

Hoschützky, H., Nimmich, W., LotTsPeich, F. \& JANN, K. (1989). Isolation and characterization of the non-fimbrial adhesin NFA-4 from uropathogenic Escherichia coli O7:K98:H6. Microbial Pathogenesis 6, 351-359.

Kanoe, M., Matsumura, T. \& KaI, K. (1992). Binding of Fusobacteritum necrophorum to bovine portal cells. Biomedical Letters 47, 47-53.

Kurl, D. N., HaAtaja, S. \& FinNe, J. (1989). Hemagglutination activities of group B, C, D, and G streptococci: demonstration of novel sugar-specific cell binding activities in Streptococcus suis. Infection and Immunity 57, 384-389.

Lämmler, C., Niewerth, B. \& Blobel, H. (1987). Neuraminidaseenhanced hemagglutination of erythrocytes by cultures of Actinomyces pyogenes. Medical Science Research 15, 1447-1448.

Lindahl, M., Holmberg, O. \& Jonsson, P. (1990). Adhesive proteins of hacmagglutinating Staphylococcus aureus isolated from bovine mastitis. Journal of General Microbiology 136, 935-939.

Miyazaki, S., Leon, O. \& Panas, C. (1988). Adherence of Streptococcus agalactiae to synchronously growing human cell monolayers without lipoteichoic acid involvement. Infection and Immunity 56, 505-513.

Nealon, T. J. \& Mattingly, S. J. (1984). Role of cellular lipoteichoic acids in mediating adherence of serotype III strains of group $B$ 
streptococci to human embryonic, fetal and adult epithelial cells Infection and Immunity 43, 523-530.

Sellin, M., Linderholm, M., Norgren, M. \& Hakansson, S. (1992). Endocarditis caused by a group B Streptococcus strain, type III, in a nonencapsulated phase. Journal of Clinical Microbiology 30, 2471-2473.

Towbin, H., Staehlin, T. \& Gokdon, J. (1979). Electrophoretic transfer of proteins from polyacrylamide gels to nitrocellulose sheets : procedure and some applications. Proceedings of the National Academy of Sciences of the United States of America 76, 4350 4354.

WEBER, K. \& OSBORN, M. (1969). The reliability of molecular weight determination by dodecyl sulphate-polyacrylamide gel electrophoresis. Journal of Biological Chemistry 244, 4406-4412.
WIBAWAN, I. W. T. \& LÄMMLER, C. (1990). Distribution of B streptococcal type antigens among streptococci of serological groups B, G and L. Zentralblatt für Bakteriologie 273, 471-477.

WIBAWAN, I. W. T. \& LÄMMLER, C. (1991). Influence of capsular neuraminic acid on properties of streptococci of serological group B. Journal of General Microbiology 137, 2721-2725.

WibAWAN, I. W. T. \& LÄMmLER, C. (1992). Relationship between group B streptococcal serotypes and cell surface hydrophobicity. Journal of Veterinary Medicine B39, 376-382.

Wibawan, I. W. T., LämmLeR, C. \& Pasaribu, F. H. (1992). Role of hydrophobic surface proteins in mediating adherence of group B streptococci to epithelial cells. Journal of General Microbiology 138, $1237-1242$ 